\title{
Article
}

\section{Eastern European film festivals: streaming through the covid-19 pandemic}

Hanzlík, Jan and Mazierska, Ewa Hanna

Available at http://clok.uclan.ac.uk/39066/

Hanzlík, Jan and Mazierska, Ewa Hanna ORCID: 0000-0002-4385-8264 (2022)

Eastern European film festivals: streaming through the covid-19 pandemic.

Studies in Eastern European Cinema, 13 (1). pp. 38-55. ISSN 2040-350X

It is advisable to refer to the publisher's version if you intend to cite from the work. http://dx.doi.org/10.1080/2040350x.2021.1964218

For more information about UCLan's research in this area go to http://www.uclan.ac.uk/researchgroups/ and search for <name of research Group>.

For information about Research generally at UCLan please go to http://www.uclan.ac.uk/research/

All outputs in CLoK are protected by Intellectual Property Rights law, including Copyright law. Copyright, IPR and Moral Rights for the works on this site are retained by the individual authors and/or other copyright owners. Terms and conditions for use of this material are defined in the policies page.

\section{CLoK}

Central Lancashire online Knowledge www.clok.uclan.ac.uk

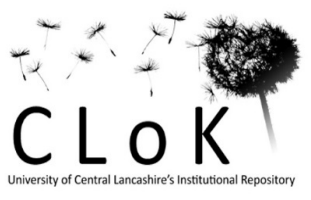




\title{
Eastern European film festivals: streaming through the covid-19 pandemic
}

\author{
Jan Hanzlík and Ewa Mazierska
}

\section{QUERY SHEET}

This page lists questions we have about your paper. The numbers displayed at left are hyperlinked to the location of the query in your paper.

The title and author names are listed on this sheet as they will be published, both on your paper and on the Table of Contents. Please review and ensure the information is correct and advise us if any changes need to be made. In addition, please review your paper as a whole for typographical and essential corrections.

Your PDF proof has been enabled so that you can comment on the proof directly using Adobe Acrobat. For further information on marking corrections using Acrobat, please visit http:// journalauthors.tandf.co.uk/production/acrobat.asp; https://authorservices.taylorandfrancis. com/how-to-correct-proofs-with-adobe/

The CrossRef database (www.crossref.org/) has been used to validate the references.

\section{AUTHOR QUERIES}

Q1 Please provide biography of the authors.

Q2 The corresponding author email address has been imported from data supplied with the original manuscript. Please revise if incorrect.

Q3 Please provide the volume number and page range.

Q4 Please update the author group.

Q5 Please note that the ORCID section has been created from information supplied with your manuscript submission/CATS. Please correct if this is inaccurate. 


\title{
Eastern European film festivals: streaming through the covid-19 pandemic
}

\author{
Jan Hanzlík ${ }^{\mathrm{a}, \mathrm{b}}$ (D) and Ewa Mazierskac
}

aDepartment of Arts Management, Prague University of Economics and Business, Prague, Czechia; bDepartment of Film Studies, Charles University, Prague, Czechia; 'School of Arts and Media, University of Q1 Central Lancashire, Preston, UK

\begin{abstract}
The Covid-19 pandemic disrupted virtually all domains of the film industry, from the production, through distribution to exhibition of films. As opposed to flourishing VOD platforms, cinemas have been hit particularly hard and with them film festivals, which had to choose between postponing their terms, becoming online or hybrid, or being cancelled altogether. The article focuses on festivals that either take place in Eastern Europe or are focused on the cinema of the region. It first briefly outlines the history of film festivals in Eastern Europe, then it summarizes the impact of the Covid-19 pandemic on cinemas and VOD platforms and finally presents three case studies of festivals and their activities during the pandemic. The three festivals streamed at least some films from their programmes and endorsed other activities, such as online industry events, drive-in cinemas and Virtual Reality events. The study concludes that the degree to which film festivals could successfully take place during the pandemic depended more on the type of festival than on its geographical location or geographical focus. Eastern European festivals were not lagging behind the West in this respect and many European festivals were, in fact, cooperating and learning from one another.
\end{abstract}

\section{KEYWORDS}

Covid-19; Film festivals;

Streaming; Czech Cinema; Polish Cinema

This article examines the place and role of streaming at film festivals either taking place in Eastern Europe or specialising in Eastern European films. It was prompted by two factors. One is the Covid-19 pandemic, which affected practically all spheres of culture and leisure, shifting from their live consumption to consumption at home, chiefly online. The second is a recognition of the growing importance of streaming in film consumption, which has been accelerated by Covid-19. The analysis focuses on three case studies: Polish Film Festival in Gdynia (PPF Gdynia), Ji.hlava International Documentary Film Festival in Jihlava (Ji. hlava IDFF), and goEast Festival in Wiesbaden. We chose these festivals to account for their different specialisms and traditions, with the PPF being a festival of Polish films, addressed principally to the Polish audience, the Ji.hlava IDFF being the leading documentary festival in the region, and goEast covering a large variety of films from both Eastern Europe and the former Soviet Union, addressed to international audience, but especially German one.

CONTACT $\otimes$ jan.hanzlik@vse.cz @ Department of Arts Management, Prague University of Economics and Business, Prague, Czechia 
We try to establish whether there is a connection between the specificities of these festivals and their willingness to embrace streaming, while taking into account the role of their location in or focus on the region of Eastern Europe. ${ }^{1}$ Our research is based on interviews with industry insiders and press releases, and is informed by existing work about streaming and its effect on film consumption at large, before and during the Covid-19 pandemic.

\section{Short history of film festivals in Eastern Europe}

The tradition of holding film festivals comes from Europe, rather than the United States and festivals were meant to provide a counterweight to the power of the Academy awards (de Valck 2007). Their origins lie in the 1930s, and especially in recognition of the power of cinema as a means to forge national identity by some European governments, especially Italy, Germany and Russia. In this spirit, the Venice International Film Festival was founded in 1932, as part of the Venice Biennale. The film festival in the French Riviera city of Cannes, originally slated to take place in 1939 , was to be a counterweight to the Venice festival. It was designed to celebrate free expression and the films of non-fascist nations. Yet, it had to wait until after the end of WWII, to materialise. In 1951, the Berlin International Film Festival (known as the Berlinale) was launched, completing the triangle of admittedly the most important film festivals in Europe and the world, along with Cannes and Berlin. These festivals were international in nature and championed arthouse cinema.

As for the Eastern bloc, the Karlovy Vary International Film Festival (KV IFF) was established as early as 1946 (originally under a different title and in the town of Mariánské Lázně). Its aim gradually shifted from being the vehicle for an expression of national identity and culture in its first edition, through a demonstration of Slavic unity in 1947 and later the unity of socialist countries, to the increasing emphasis on business and international sales between East and West in the 1950s (Bláhová 2015). In 1960 (after two previous attempts in 1955 and 1956), the German Democratic Republic founded an annual documentary film festival in Leipzig exhibiting films from socialist countries and by western leftist filmmakers. It did so in response to the film festival in West Berlin, which showcased 'Hollywood glamour and Western show business [and was] meant to provoke East Berlin and to needle the Soviet Union' (Elsaesser 2005, 84; see also Kötzing n. d.). Yet despite the early emergence of KV IFF and some other reactions to Western festivals, there have been no events in Eastern Europe that would rank among the most important European film festivals. Their absence can be explained by world-system theory, which uses the concepts of core/centre, semi-periphery and periphery ${ }^{2}$ (Wallerstein 1990; Wallerstein 2004; Szczepanik, Zahrádka, and Macek 2020) to show the unequal distribution of economic power among countries. Eastern European countries constituted periphery or semi-periphery of Europe and the realities of the Cold War confirmed and added to this status, as (with small exception) during the period of state socialism the economic distance between countries such as Poland or Hungary and the West had increased. During the state socialist period, these countries were also at the semi-periphery, albeit in a different configuration, with Moscow as the centre. Not surprisingly, in the context of the Eastern bloc, one of the two most important festivals was the Moscow International Film Festival, running regularly since 1959 and held every second year in July, from its inception alternating with the KV IFF, which ran since 1948 as an international film competition. The history of KV IFF points to the advantages and disadvantages of being part of the socialist bloc. Its long history, as 
well as the fact that Czechoslovakia was among the least peripheral parts of Eastern Europe (Wallerstein 1990, 50), points to its status as the only festival in Eastern Europe, which had a chance to receive 'A' status. However, its linkage to the Moscow festival weakened its connection to other leading European film festivals, whilst augmenting its prestige in Eastern Europe. Still, Eastern European festivals played an important political and cultural balancing role and attempted to build an alternative canon to the European arthouse canon offered by film festivals organized in the West.

The fall of the Berlin Wall, on one hand, and the changes in the consumption of films and culture at large, on the other, led to proliferation of film festivals in Eastern Europe. The former facilitated the cultural exchange between the European West and the East, as well as the rest of the world; the latter affected the relation between film festivals and normal distribution. While in the past film festivals in Eastern Europe were seen primarily as a means to augment cinematic and wider cultural circulation within the Eastern bloc, after 1989 many film festivals in Eastern Europe, such as New Horizons Festival in Wrocław, which is among larger European film festivals in terms of tickets sold, focus on bringing local audiences to films that are presented as significant artworks of western and global cinema. Hence, these festivals can be seen more as instruments of cultural imperialism, reinforcing a sense of western cultural superiority over its eastern counterpart, than of promoting and boasting national and regional culture, reflecting the economic and social realities of the world as presented by Wallerstein. Moreover, while in the past festivals were seen as a means to increase normal distribution, these days they often replace it (Martinek 2014), as both annual film festivals and one-off events are becoming more attractive than standard theatrical distribution (Hanzlík 2017). Increasingly, film festivals are also multi-media affairs, including, apart from film screenings, concerts, fine arts and photo exhibitions, and theatre performances. This reflects a more general trend of 'festivalisation of culture', namely reducing culture to extraordinary 'events', which are consumed from time to time, rather than all year round (Bennett, Taylor, and Woodward 2014). Eastern Europe has not been immune from this trend. Currently, many festivals in Eastern Europe are mega-festivals, as the previously mentioned New Horizons Film Festival, which includes concerts, art exhibitions and performances of contemporary dance. Péter Virginás observes in relation to Transilvania International Film Festival, that its organisers are aware that 'the festival crowd is not only constituted by avid cinephiles and, at the same time, that cultural consumption preferences may extend beyond cinema' (Virginás 2017).

It is difficult to say how many film festivals existed and are currently held in Eastern Europe, in part because not all festivals used to use this name. Many festivals started their existence as 'overviews' and morphed into 'festivals' in the course of time. The Czech National Information and Consulting Centre for Culture registered 47 film festivals in Czechia in 2019 that take place annually (NIPOS 2020). In Poland this number is about 90, according to the report about Polish film festivals (Drzal-Sierocka, et al. 2017, 7). If one-off festival-like events and overviews would have been counted, the number would likely be significantly higher. It is fair to say that most towns and cities with a population exceeding 200,000 have some form of film festival, either as a free-standing event or as part of a larger event. These festivals can be divided into several categories. Perhaps the most prestigious category and also the one most visible in media are non-specialised competitive film festivals, showing premiere films, with the focus on films from the region. This includes the previously mentioned KV IFF, Warsaw Film Festival, held every year from 1985, and Tallinn 
Black Nights Film Festival, organised from 1997. In common with older festivals, such as Cannes and Berlin, they are major industry events and can be labelled 'business festivals' (as opposed to 'audience festivals'), which in the taxonomy of Mark Peranson involves amongst other things high budgets, orientation on world or international premieres, guests for most films attending the festivals, market and business presence, and major competitions (Peranson 2008, 27). However, even though for example KV IFF dedicates a lot of energy to its film industry activities and events, its international significance in terms of film business is considerably lower than that of its western counterparts, especially Cannes, Berlin, and Venice, and to compensate for this the festival has prided itself in drawing large audiences from the general public too. This can be viewed primarily as a consequence of the above mentioned segmentation of the world into the centre, semi-periphery and periphery, and the disinterest of the centre in semi-peripheries and peripheries. Another category are national film festivals, which show films produced in a given country every year. An example is PFF Gdynia, on which we will focus in due course, or Finále Plzeň in Czechia. Then we should list specialised film festivals, such as the CineFest Miskolc International Film Festival, founded in 2004, with a focus on filmmakers under the age of 35. There are currently two larger festivals specialized in animated films in Czechia, Anifilm in Liberec and PAF (Přehlídka animovaného filmu) in Olomouc, the significance of which is obviously incomparable to the similarly specialized but far more prestigious Annecy International Animation Film Festival. Several Eastern European countries have festivals of documentary cinema, such as the already mentioned DOK Leipzig or Ji.hlava IDFF, which will also be detailed below. Then there are film festivals specialising in human rights, such as Media Festival Human in Danger in Lodz, which started in 2000, or One World International Human Rights Documentary Film Festival, which started in 1999 and takes place in cities all around Czechia. Another category are non-specialised festivals held in Eastern Europe, focusing on arthouse cinema from all over the world. Finally, we shall list festivals focused specifically on Eastern Europe. Not surprisingly, such festivals are organised in Germany: Cottbus, from 1991 and Wiesbaden, from 2001, reflecting Germany's status as a bridge between the East and the West and whose mission is to increase the visibility and status of Eastern European films in Germany, Europe and worldwide.

The sample of case studies of festivals presented in this study was selected with the above-mentioned context in mind and based on the following further criteria. Firstly, the academic literature has so far been focusing predominantly on Western festivals, whereas Eastern European film festivals have been addressed only marginally (studies of Czech festivals include e.g. Bláhová 2015; Děcká 2014; Havel 2012; Jiřiště 2014; Martinek 2014; studies of Polish festivals include e.g. Pabiś-Orzeszyna 2015; Drzał-Sierocka, et al. 2017). Thus, we wanted to complement the growing body of studies on festivals by analysing nationally or regionally significant festivals that either take place in this region and/or are focused on the region. Secondly, as one of the aims of the study is to assess streaming activities of festivals during (and after) the Covid-19 pandemic, only such festivals were selected that were not cancelled and, on the contrary, actively endorsed and developed their online activities. Thirdly, the selection of cases was led by the logic of maximum variation sampling (Seidman 2006, 52-56; Patton 2015, 428-429): All the cases are considerably different from one another, which makes it possible to cover both their diverging and shared characteristics. However, we have included in the sample only festivals that have had a relatively long tradition and their practices had been to a large degree stabilized before the Covid-19 
pandemic. By this decision we forwent, for example, a number of vibrant festivals that take place in the Baltic and Balkan region, although they certainly should be explored in future research endeavours.

Polish Film Festival in Gdynia is a non-specialized festival focused on a national production of a single country and at the same time 'the most important Polish film event' (Polish Film Festival Gdynia 2021). Ji.hlava International Documentary Film Festival, as the title indicates, is a festival specialized on documentary films that features competitions of both world documentaries and documentaries from the region of Central and Eastern Europe. The festival characterizes itself as 'one of the leading European documentary film festivals and the largest event of its kind in Central and Eastern Europe' (Ji.hlava IDFF n. d.). The festival goEast is the only one in the sample that takes place, geographically speaking, outside the former Eastern Bloc, although its focus is on Central and Eastern European cinema, of which it considers itself to be 'one of the most important international centres' (goEast n. d.). Thus, it represents a Western (i.e. central) perspective of the cinema of the Central and Eastern European (i.e. peripheral or semi-peripheral) region. The presented study is based on interviews with Tomasz Kolankiewicz, the Artistic Director of the Polish Film Festival in Gdynia, and Heleen Gerritsen, the Head of goEast. The case study of Ji.hlava IDFF summarizes a study of the festival by Alice Teslíková (2021) and complements it by other sources of information, such as interviews in media and film industry debates.

Before we turn our attention to the three festivals themselves, we will briefly summarize the development of the infrastructure that festivals have depended on before and during the pandemic era.

\section{Public film screenings during covid-19}

As film festivals have been, since their beginning, associated with screenings in public venues, strategies adopted by film festivals facing pandemic Covid-19 necessarily rely on the situation cinemas find themselves in. The restrictions imposed by states on the operation of cinemas in response to the Covid-19 pandemic appear to be (at least in the Eastern and Central European context) similar in different countries, even if their timing was individual. Cinemas were either completely closed or opened with special hygienic measures, limitations placed on their seating capacity and a ban on the sales of food and drinks. Even when cinemas were allowed to show films between pandemic waves, the ban on concession stands made it impossible for multiplexes to reopen because sales of food and drinks can make as much as one third of their total revenue (DVTV 2021). And even though independent cinemas are not that heavily dependent on the sales of food and drinks, the closure of multiplexes negatively affected the whole ecosystem of public film screening.

Given the 'precarious under-capitalised situation' the arts sector was facing even before the pandemic (Brown 2020), such restrictions had obviously harsh effects upon cinemas, many of which would not be able to survive the crisis without a relief provided by governments. Relief for culture has differed in individual states according to their traditions (e. g. their involvement in culture before the pandemic) and overall economic standing (Betzler et al. 2020). The situation was for example, particularly bleak in Slovenia, where arthouse cinemas saw their state funding cut by half (Vinter 2020) and protests were even held because of delayed payments by the state to filmmakers (Vinter 2021). Cinemas themselves made various efforts at alternative screenings of films but such attempts could not possibly replace 
the normal business model within which they operate (see e. g. Kancereviciute 2020). These included re-establishments of drive-in cinemas, with significant success in the case of Lithuania facilitated by new LED screening technology (Kancereviciute 2021), sales of cinema vouchers (Grynienko 2021), and the so-called 'virtual cinema' (Sterritt 2020) online streaming that allows viewers to pay to a particular physical cinema of their choice for the 'ticket' while watching films in their homes.

Delayed premieres of American blockbusters in some cases lead to a significant increase in the share of domestic films in cinemas (when they were opened). For example, in Slovakia the share of domestic films almost doubled (Točíková Vojteková 2021) and in the case of Czechia the film $V$ siti/Caught in the Net (2020), directed by Vít Klusák and Barbora Chalupová saw a huge success both online and in cinemas during the summer when they were open, as it did not face the competition of American productions (Stejskal 2021). The same situation took place in Poland. Between Polish lockdowns, when Polish cinemas opened again, the biggest success achieved two Polish films, 25 lat niewinności. Sprawa Tomka Komendy/25 Years of Innocence. Tomek Komenda Affair (2020), directed by Jan Holoubek) and Pętla/Loop (2020), directed by Patryk Vega, achieving respectively 711,000 and 569,000, which was more than Hollywood productions of Warner and Disney (Adamczak 2020b).

However, premieres of many films intended for theatrical release were postponed and as the head of the Czech Film Fund Helena Bezděk Fraňková noted in a recent film industry debate, 'At the moment, the winners of the pandemic are obviously Netflix and Amazon.' What she meant by that was not only the increasing use of those platforms by viewers but also their production activities, because subscribers have been eager to see new films and series (Telegraph Olomouc 2021), which could only be delivered online during lockdowns. The development led some authors to speculate that VOD platforms will 'switch consumers from going to movie theatres' because during lockdowns they have 'discovered an alternative that is more convenient, affordable, and accessible' (Sheth 2020, 282). This view, however, fails to recognize the social aspect of cinema going, an activity that has already survived the coming of television and home video.

Marijke de Valck and Antoine Damiens noted that festivals organized during the pandemic in various parts of the world evidenced 'the resourcefulness, adaptability, and creativity of festival organisers who had to, very quickly, find local solutions to a global calamity' (de Valck and Damiens 2020). As with premieres of films, many film festivals were postponed to a more promising date. Some festivals made use of the above-mentioned alternatives to regular screenings - from the employment of drive-in cinemas to becoming hybrid or fully online. Venice International Film Festival provided viewers with online access to Virtual Reality content and Virtual Reality panels and meetings where people were able to communicate (Armstrong 2021, 12-13). Both Venice and Sundance Film Festival hosted some physically distanced physical events, sometimes even in distant, 'satellite' locations (Armstrong 2021, 10-13). In fact, of major film festivals held annually in Czechia, only the festival Krrr! was completely cancelled in 2020 and this was due to the fact that the festival specializes in screenings of $70 \mathrm{~mm}$ films, which is an experience that cannot be reproduced through online streaming (Ševčík 2021, 30-31). Despite all the effort, festivals in various parts of the world faced the problem, as Phil Hobbins-White and Brad Limov put it, of the unsatisfied 'desire for the energy of a live event and the intimacy of the interactions' among 
filmmakers and between filmmakers and their audiences (Hobbins-White and Limov 2020, 336).

\section{The advantages and disadvantages of streaming}

Before the onset of the Covid-19 pandemic, video-on-demand (VOD) platforms and online viewing had been rapidly developing for a decade, although with differences among individual states and between the centre, semi-periphery and periphery. As Petr Szczepanik, Pavel Zahrádka, and Jakub Macek argued, 'national borders, center-periphery hierarchies and differences in scale still matter [in the digital era], and perhaps they matter even more than in the analog broadcast era' (Szczepanik, Zahrádka, and Macek 2020, 1). For example, the growth of the VOD market in the UK has been considerably bigger than in France, Germany, or Italy (Smits 2019, 150). The VOD market in Poland has been less advanced than the markets of Western states but significantly more developed than the markets in Czechia and Hungary (Adamczak 2020a, 150). Such differences notwithstanding, watching TV and movies has been identified as the single most commonly used strategy of coping with isolation during the pandemic (Taylor et al. 2020, 712), and in consequence the year 2020 saw further intensification of online viewing both in the West and in Central and Eastern Europe. This is the case both of global platforms, such as Netflix and Amazon, and various independent VOD platforms, some of which registered an astonishing increase in the number of subscribers. For example, the number of subscribers to the Czech arthouse VOD platform AeroVOD increased tenfold between 2019 and 2020 (Míšková 2021).

Thus, the infrastructure for online streaming was well-developed already before 2020 , and when the pandemic arrived it was readily at hand for film festivals. In fact, online film festivals date at least as far back as 2012 (see Nedyalkova 2016), although initially a relatively small part. There were several reasons why festivals embraced streaming. Probably the most important was the limited capacity of the venues, not only in terms of housing the audience, but also showing films in the available slots. As a result, many interesting films, offered to festivals, had no chance to be shown in official programmes. Streaming overcame this problem, although at the cost of creating a two-tier system, with less commercial, indie and short films being more likely exhibited through streaming (Rosen 2013; Powers 2020). Another reason for introducing streaming was a desire to overcome physical boundaries and reach new audiences, not only potential viewers living in other cities and countries, but also those who have problems with accessing cinemas due to disabilities or parenting responsibilities (Powers 2020). Moving online also allowed to engage filmmakers, who otherwise won't be able to travel to given festivals. A third reason was a grudging recognition that streaming is becoming the main way of accessing films and institutions which ignore this fact would be left behind, as all institutions which reject innovation (Powers 2020).

The role of streaming differed from festival to festival. Whilst in some they played only a small part, adding 'spice' to the traditional format, other embraced it as an essential part of their activities. This, to a large extent, depended on the willingness of distributors and filmmakers to engage in this type of exhibition. While initially it was seen as a 'second-hand' type of screening, gradually it gained in respectability. One can notice a correlation between the changing status of this type of screening and the growth in prestige of films made by streaming platforms. From this perspective, the production and the subsequent successes of Roma (2018), directed by Alfonso Cuarón, which was produced by Netlix and received 
an Oscar for the best film, played a major part in this shift. The director himself dignified Netflix as a respectable film producer and presented watching film at home as a means of providing an experience on par with watching it on a large screen (Butter 2019). It is thus not surprising that some festivals joined forces with large VOD services, as was the case of the festival South by Southwest, which offered festival films via Amazon Prime Video (see Hobbins-White and Limov 2020).

\section{Polish film festival in Gdynia}

The purpose of the PFF is the promotion of Polish cinema. It is the oldest and most important festival with such a remit and admittedly the most important festival on the calendar of film festivals in Poland. The PFF emerged in the 1970s out of the initiative of the Gdańsk circle of the 'Żak' Film Discussion Club $^{3}$ and the Polish Filmmakers Association. The festival exists since 1974; until 1986, the PFF was organised in Gdańsk; then Gdynia became its venue, and the Danuta Baduszkowa Musical Theatre became the Festival Centre. Each year, the PFF audience can familiarise themselves with the recent Polish productions; often Polish films had their premiere at the festival, competing for the Golden Lions and Silver Lions as well as a number of individual awards. The event is attended each year by approximately 2,000 film professionals from Poland and abroad: filmmakers, actors, producers and festival programmers. The most important part of the PFF is a competition for the best full-length fiction film, not least because this is one of the most covered events by the Polish media. Moreover, the winners in this competition go to compete in international festivals and for the Oscars. Awards at the PFF also increase the films' taking at the box office.

Currently, the Pomeranian Film Foundation in Gdynia is the producer of the PFF, and its organizers are the Ministry of Culture and National Heritage, the Polish Film Institute, the City of Gdynia, the Pomeranian Province Government, the Polish Filmmakers Association. Several dozen institutions, sponsors and media patrons engage in the organisation of the event each year. The relation of the Festival to Gdynia is of particular significance - the PFF is one of the most important events in the life of the city, which essentially influences its development and image.

The fact that the PFF is focused on films which collect most of its revenue from screening in cinemas and from which a significant part has their premiere at this festival, explains to a large extent its attitude to streaming: it was little used prior to the Covid-19 pandemic, and the purpose of its use was only to hold industry meetings. For this reason the festival's 46th edition in 2020 hung on balance, because distributors of the films which didn't have by this point their cinema premiere, did not want them to be available online before they were exhibited in cinema, in part out of fear of piracy and in part not to undermine the normal order of distribution windows - from cinema to television, via streaming platforms. Given that, and in the light of the second wave of the Covid-19 pandemic, the initial decision was to cancel the festival, but it was reversed due to the pressure exerted by the Polish film industry, which did not want to give up on their most important event. However, the festival was moved from its usual time in September to December. These changes put a great pressure on the organisers of the festival, as they had only five weeks to prepare the festival in a new format, making sure that they have the right technology in place and comply with a complex set of requirements made by film distributors. 
Streaming, inevitably, was employed there more sparingly than at other Polish festivals. Even though some distributors in the end agreed to stream their films, the audience was limited, for example to only 2000 viewers, or only accredited guests. Only a small percentage of films originally planned to be shown were in the end streamed that year in the main competition and some of the 'heavy-weight' productions, such as Sweat (2020) by Magnus von Horn and Śniegu już nigdy nie będzie/Never Gonna Snow Again (2020) by Małgorzata Szumowska, were not presented because of their distributors' embargo. It could be argued that this lowered the standard of the competition and the value of the awards. On the other hand, however, it allowed recognition of the films which, otherwise, might not attract much attention. In this context it is worth mentioning that the festival's grand prix was awarded to an animated film Zabij to $i$ wyjed $z$ tego miasta/Kill It and Leave This Town, directed by Mariusz Wilczynski and it was the first time in its history that an animated film got this award. Although such a result might be in part attributed to the jury being headed by Lech Majewski, himself a painter and author of acclaimed animated films, the fact that there were fewer films in competition could also play its role.

While streaming resulted in a big hole at the centre of the festival, it did not affect negatively other parts of the festival, such as short film competition, numerous non-competition sections and industry meetings, because there was no danger that as result of moving these events online, much or any revenue would be lost. For example, documentary films normally do not receive theatre distribution, therefore moving them online does not result in diminishing their exposure to the audience. It is likely that the opposite was the case, namely more people watched these films thanks to them being streamed than shown in a real cinema. In terms of the entire audience, about 50,000 people watched the PFF in 2020, as opposed to about 70,000 which the festival attracts on average in non-pandemic times.

There were two additional advantages of the 'streamisation' of the PFF. One was allowing more guests to participate in industry events and forums, including regional politicians, who took part in discussions about developing cinema culture in the Polish regions. It is likely that such discussions would have a tangible impact on increasing subsidies for the Polish film industry. Streaming and, more broadly, moving a large part of the Festival activities online, brought more stakeholders in the Polish industry together. It also allowed for a better cooperation and coordination between the PFF and other Polish festivals.

Another positive effect were savings in the festival budget of about 500,000 Zloties, which amounted to 10 per cent of its entire budget. This was done thanks to cuts in travel of (mostly) overseas guests and decreased use of hotels. By the same token, these savings had a positive environmental effect. When we asked whether these cuts and savings affected staff working on the festival, Tomasz Kolankiewicz replied that 'no' or only in a minimal way, as much effort was put in keeping employment at the same level as in the previous editions, by redeploying staff working 'on the ground' to more virtual tasks. He was not certain if this was also true about the festival sponsors who provided support in kind, such as transport of the guests. It is possible that some cuts were made on the way.

Despite these positive developments, Kolankiewicz is of a firm view that the future of the PFF should be in material cinemas rather than online. This is because of the specificity of 'his' festival, as well as due to a more essential reason of cinema's experience. Evoking Jean-Luc Godard's insistence that cinema is not the same as films, he mentioned in our conversation that cinema began with the first public screening of the films by Lumière brothers, rather than with the invention of machines producing and screening films. 


\section{Ji.hlava international documentary film festival}

Ji.hlava IDFF was founded by a group of high school students in 1997, and has taken place every year since then. It grew from an event for a small number of people to a festival with an international significance and thousands of visitors, including directors Jørgen Leth, Želimir Žilnik, Krzystof Zanussi and Cristi Puiu, and scholars Marijke de Valck, Thomas Elsaesser, Aida Vallejo, and Dina Iordanova as guests. It features several industry activities, such as 'Emerging Producers' for a new generation of promising European producers, 'Festival Identity' for festival organisers and programmers, and 'East Silver' market focused on the region of Central and Eastern Europe. The main competition 'Opus Bonum' features films presented in international premieres, other prizes are awarded to films from the region of Central and Eastern Europe and to Czech documentaries. The festival is characteristic of crowded screenings with lively debates and vibrant atmosphere in an otherwise small city in the cold month of October. The transformation of Ji.hlava IDFF from an offline to online version was detailed in a study written by the Head of Production of the festival, Alice Teslíková (2021). Her conclusions will be briefly summarised here and complemented by information from other sources.

Despite the circumstances and the fact that the festival was held solely online, the 2020 edition seemed successful. As opposed to the Polish Film Festival in Gdynia, Ji.hlava IDFF was able to stream 310 films in 2020 (Ji.hlava IDFF 2020, 13). The authors of the festival 'Final Report 2020' note that the streamed 'films registered over 56 thousand views' and, as Marek Hovorka, the Festival Director, noted, '[a]ssuming that one third of streams were watched by two people, we have reached almost 75,000 viewers' (Ji.hlava IDFF 2020, 4; see also Teslíková 2021, 56). According to Hovorka, the number of accredited viewers (not counting journalists and film industry representatives) doubled in comparison to the preceding edition (Sladký 2020), which could mean that the festival was probably able to reach viewers who would not be normally able to come to the festival, were it held offline. And while we cannot evaluate a festival's success using merely audience statistics, especially as in many instances festivals intentionally delimited the numbers of online viewers for individual films, these figures seem big enough to indicate that the organisers' effort had a favourable outcome in the case of Ji.hlava IDFF.

There are several reasons behind this relative success. It was apparent from our interviews that the character of documentary film festivals is in some ways different from festivals of fiction films. Firstly, as Kolankiewicz mentioned in our interview, 'when it comes to documentaries, probably around 95 percent of the films never go to cinemas.' And because they are less often released through regular theatrical distribution, holdback periods are not completely preventing them from being streamed by festivals. Nevertheless, festival streaming needs to be geo-blocked and limited in capacity. Hovorka mentioned that, during the negotiations, the most difficult aspect was to persuade Czech producers and distributors to provide their films to the online edition of Ji.hlava IDFF. This was so because they did not have previous experience with online festivals, while foreign film industry representatives had already taken part in the online editions of CPH:DOX and Visions du Réel documentary film festivals (Sladký 2020, see also Teslíková 2021, 61-62).

Secondly, documentary film festivals do not need to resolve difficulties other festivals may face, such as those targeted at children. The artistic director of Zlín Film Festival - The International Film Festival for Children and Youth, Markéta Pašmová, noted in a film 
industry debate during the summer 2020 that smaller children cannot read subtitles and films for them need to be classified and presented according to age limits, which is difficult to secure for streaming (KV IFF and Kancelár Kreativní Evropa - Media 2020). That said, Ji.hlava IDFF did organise its traditional small programme for children even in its online version (Teslíková 2021, 56).

Thirdly, as Aida Vallejo noted, documentary film has been historically 'a testing ground' for experimentation 'that challenged conventions of cinema and expanded its scope to new media landscapes', as opposed to the technologically and aesthetically more conservative fiction film (Vallejo 2020, 17). Jihlava IDFF demonstrated that documentary cinema can be a testing ground not only in terms of production but also in terms of film exhibition: According to Andrea Slováková, one of Ji.hlava IDFF's programmers, the festival started 'the first online platform run by a festival' as early as 2005 (Slováková 2020b, 201). Thus, the festival, in fact, has been hybrid already since 2006 and streamed some parts of the programme even before the onset of the pandemic (LFŠ 2020). This was surely an advantage as three weeks before the start of Ji.hlava IDFF, the staff was still preparing for an offline version and had to switch to the online version rather fast (Ji.hlava IDFF 2020, 1). Another possible reason behind the success of the festival was the fact that it took place relatively late during the pandemic. Those festivals that were held later in the year were in general able to build on experiences of festivals that preceded them (Volná 2020, 40, see also Teslíková 2021, 81). At least in the case of documentary cinema, it was particularly major Western festivals (CPH:DOX and Vision du Réel) that led the way.

As was already mentioned, the festival had to resolve initial scepticism of filmmakers regarding the disruption of the usual sequence of distribution windows - festivals, online distribution, television broadcasting. It also had to withdraw some films from its programme, even though it was able to include some other films instead (Teslíková 2021, 61-64). Some accompanying events had to be cancelled and a traditional section dedicated to Virtual Reality films had to be reduced only to such films that did not require advanced technological devices and could be viewed with adjusted smartphone screens at homes (Slováková 2020a). The industry programme ran successfully online, with some activities registering lower attendance than expected but on the other hand enjoying the participation of guests from afar who would not be normally able to come to Jihlava (Teslíková 2021, 82). The budget of the festival remained, more or less, the same, although its structure changed significantly. As one would expect, the money initially allocated to travel expenses and accommodation of guests had to be moved to fund web development and other technological issues. Nevertheless, the festival did not suffer any financial losses owing to the support from the Ministry of Culture of the Czech Republic, Czech Film Fund, the City of Jihlava, The Vysočina region, and other institutions, such as embassies (Teslíková 2021, 69 and 82 and Sladký 2020). Hovorka mentioned in an interview that there was not a single partner of the festival that would not accept the transformation of the festival to an online edition (Sladký 2020).

Teslíková emphasised in her study that the festival was able to reach viewers easily through its online platform but on the other hand, it is not possible for an online event to retain the festival atmosphere in the long term and the online edition also generates cultural and financial losses for the locality where it takes place (Teslíková 2021, 66-67). Hovorka himself in an interview seemed to be in favour of continuing the festival in a hybrid form in the future. As he mentioned, 'For some people the physical experience [of a festival], 
meeting with other people and discussions will be a value that will make it worthwhile for them to come to a festival' while others, according to him, may take the opportunity to watch films online during the festival' (Sladký 2020).

\section{GoEast - festival of Central and Eastern European film}

The goEast film festival, launched in 2001, was founded by Claudia Dillmann, the former director of Deutsches Filminstitut (DIF). In the foreword to the first festival catalogue she wrote: 'The time has come to open ourselves to the thoughts, images, myths and stories of our Eastern neighbours. To their culture. To their films. These words suggest that the goEast is dedicated to films from Eastern Europe or, more precisely, to the films made in countries, which previously belonged to the Eastern bloc, namely the Soviet Union and the satellite countries.

From the outset, the state capital Wiesbaden and the Hessian state government showed considerable interest in goEast and emphasised this engagement with substantial support. It was in Wiesbaden, a city maintaining rich historical ties with Eastern Europe, that the festival found a home in the Caligari FilmBühne, one of Germany's finest cinemas. The Festival normally takes place in the late April, for a week. As a project of Deutsches Filminstitut \& Filmmuseum e.V. (DFF), goEast has dedicated itself to the task of bringing the diversity and richness of Central and Eastern European cinema into the heart of the West' and to strengthening the place of these prestigious films in the public consciousness, given that Eastern European films are still under-represented in regular cinemas. It includes possibilities for networking; exchange and training are offered within the scope of the EAST-WEST TALENT LAB and other programmes for young talents. An important part of the programme is the Symposium: a series of semi-academic lectures and discussions, often focusing on less-known aspects of the history of Eastern European Cinema. Mazierska took part in several such events, dedicated to the Polish New Wave and the history of Eastern European music video, among others. GoEast receives around 400 professional visitors and 12,000 cinema visitors annually.

Before 2020, streaming of films at goEast never took place. There were occasional situations when a guest who was unable to travel, joined an event online, for example in a seminar about music videos, when the guest communicated via Skype. These were, however, exceptions. In 2019 a decision was made to record the Symposium for the purpose of archiving it. Preparations for that were made, such as hiring a video crew. In hindsight, this proved a good decision, because when the pandemic happened, some of the organisational changes required for the shift online were already in place. Most of the adjustments needed to be made in the short notice. Due to the fact that the goEast is organised in April-early May, in 2020 it was one of the earliest film festivals globally and the first in Germany which practically coincided with the first wave of the pandemic in Europe. Consequently, organizers of goEast had to make a decision whether to cancel the Festival, postpone it or move online. It chose the last option, as cancelling would mean letting down people working for it, as well as its numerous partners and, of course, the audience. This shift required, among other things, redeploying staff, from working 'on the ground' to working in the digital environment, preparing events taking place online, revamping the festival website to be suitable to the new type of festival and negotiating with guests and partners the new format of film exhibition and events. Unlike the PFF, goEast did not experience problems with the 
distribution of films, even those which were meant to have their premiere there. One reason for that was limiting the number of viewers to the numbers that would fit in physical cinemas, which was acceptable for the rights holders. Another is the status of the competition: although the Festival offers awards, the competition is of less importance there than at Gdynia Festival.

Asked how it affected the staffing and budget of the festival, namely whether they were able to make savings, Heleen Gerritson replied that they did not. They needed as many people to work during the festival as in normal times and could not reduce their budget, despite cutting costs on travel and hotels for the guests. If anything, they would do with more money. Savings on travelling costs were put largely into overcoming technical problems with organising events online. In terms of screening films, the festival used first Vimeo, due to its relative cheapness and familiarity with this platform, as it was used for professional guests in previous years, but in 2021 it moved to a more specialised platform when the festival was, again, held online. The deal was that the number of tickets sold was capped in line with the usual number of tickets sold in cinemas. According to Gerritson, the festival benefited from the help of dedicated team of programmers from Russia, Poland and Ukraine, whereas the organisers would not be able to afford the technological infrastructure that included interactive elements if they depended on Western European technological companies.

In 2020, moving goEast online affected the decision regarding the films included in competition. The Festival decided not to stream premiere films, as it regarded it as unfitting to deprive them of the 'proper premiere.' There was hope that these films would be screened later. For this purpose, the Festival was extended till autumn, with the Symposium taking place in summer. Although the films were not available to the audience in a cinema theatre, the jury could watch them in the cinema. This was because premises could stay open in Germany for business purposes, and the Festival used this loophole to ensure that the jury had access to films in their 'proper' format.

We asked whether the changing of the festival formula affected the accessibility of films, especially in relation to disadvantaged viewers, such as people with disabilities and parenting responsibilities. Gerritson responded that it would be impossible to prove, as she had no access to personal characteristics of her viewers, but judging by the viewing figures, the festival reached some new audience. In particular, one film, which in the opinion of Gerritson would probably attract about 30 people in the cinema, was watched online by 200 people, suggesting that participation widened considerably. It is also possible that participation widened due to extending the period of the festival and made some films available in the other parts of the country and other festivals.

Apart from screening films, an important part of goEst is the Symposium. This event took place in 2020 in a cinema in a blended form, with some lectures being pre-recorded. By 2021, it moved online entirely. As with Ji.hlava IDFF, an element of the festival took a form of virtual reality, a media activity initiated by goEast already in 2018 and enabled by VR headsets or PCs. A replica of the main festival cinema was created especially for the purpose of its online version of goEast. Visitors could enter this cinema from their PCs wearing avatars and special tours were offered to them.

It is likely that certain online aspects of the festival would outlive the pandemic and become its permanent fixture. They included pre-recording lectures for the Symposium, offering the festival films for streaming after the main festival and the use of virtual reality in making the films more accessible and entertaining for the audience. 
Although, by and large, the shift online can be regarded as very successful in the case of goEast and even allowed it extra publicity thanks to being a pioneer and trend-setter in this respect, its director remains adamant that streaming is not the right direction to take by film festivals. According to her, all platforms used by festivals look similar, the result of which is that all online festivals have the same feel to them. Online events can add 'cherries' to the festival 'cake', but this 'cake' needs to be consumed in the physical space of brick and mortar cinemas, accompanied by people wearing material clothes rather than avatars.

\section{Conclusion}

It is apparent that the ability of individual film festivals to cope with the Covid-19 pandemic in 2020 by going online was significantly influenced by their specific foci and characteristics. For documentary film festivals, such as Ji.hlava IDFF, it was easier to obtain rights for online streaming. On the other side of the spectrum are events such as the Polish Film Festival in Gdynia that are more lavish and exhibit films with high expectations in terms of domestic and international sales, the result of which is that only a limited number of films can be streamed.

At the same time, it seems that some aspects of festivals, especially film industry activities, can be held online regardless of the type of festival, and almost as effectively, with some advantages and disadvantages of their online versions. In 2020, both Ji.hlava IDFF and goEast continued with experimentation with Virtual Reality initiated already before the pandemic, as did some major Western festivals such as Venice. These experiments were either in the form of social events or streamed films, the latter of which was facilitated by recent developments of mobile phones that can now be used as VR headsets by viewers at home. In the case of goEast, a drive-in cinema was also used for screenings as a suitable alternative to regular cinemas. However, it seems that such activities were on the margins of physically happening festivals before the pandemic and will probably return to the margins once the physical versions of the festivals can take place again. In all the three cases the festival organisers plan to go back to physical cinemas when they are allowed. Again, only the documentary film festival in the sample, Ji.hlava IDFF, seemed really enthusiastic about retaining some of its online activities in the post-pandemic era and expanding on its hybrid form initiated already before the pandemic.

It is clear that festivals taking place in the region of Central and Eastern Europe or focused on the cinema of this region are relatively less influential than their western counterparts in terms of cultural prestige or international sales. But in the global era (despite current limitations on travelling), festivals in general were able to learn from one another and share their experiences. In this context festivals in Eastern Europe or focused on Eastern European films were not sidelined but instead they made use of all known options and developed ways to get to viewers in the difficult times. In the case of the goEast festival, they were even trailblazers, due to adopting early the online format, which was recognised by the media. Given that Eastern Europe is often seen as the province of Europe, lagging behind the more advanced West, we can thus argue that this was not the case in implementing this technological innovation. At the same time, in this part of Europe we find great attachment to the traditional format of film screening, perhaps resulting from the fact that in Eastern Europe cinema is still seen as a civic institution, to a large extent competing with political authorities in forging imagined communities. People involved in 
festivals seem to be weary that online festivals would lose this role and, in our opinion, this anxiety is justified.

\section{Notes}

1. We use the term "Eastern Europe" here in the historical-political sense, i. e. to denote former state-socialist countries in both Central and Eastern part of Europe.

2. Some authors complement these terms by the concept of semi-core (Bohle and Greskovits 2012).

3. This reflects the strong involvement of film clubs in development of film culture. Virtually all Polish film festivals were children of film clubs.

\section{Disclosure statement}

No potential conflict of interest was reported by the authors.

\section{Funding}

This work was supported by the European Regional Development Fund project "Creativity and Adaptability as Conditions of the Success of Europe in an Interrelated World" (reg. no.: CZ.02.1.01/0.0/ 0.0/16_019/0000734) and by the Technology Agency of the Czech Republic (project TL04000421).

\section{ORCID}

Jan Hanzlík (D) https://orcid.org/0000-0002-8387-4293

\section{References}

Adamczak, Marcin. 2020b. “Ostatnie seanse filmowe." Dwutygodnik, 8. Accessed 12 May 2021. https://www.dwutygodnik.com/artykul/9084-ostatnie-seanse-filmowe.html

Adamczak, Marcin. 2020a. "Industry Divide: The Interdependence of Traditional Cinematic Distribution and VOD in Poland." In Digital Peripheries: The Online Circulation of Audiovisual Content from the Small Market Perspective, edited by Petr Szczepanik, Pavel Zahrádka, Jakub Macek, and Paul Stepan, 145-157. Cham: Springer. doi:10.1007/978-3-030-44850-9. Accessed 25 May 2020. https://link.springer.com/content/pdf/10.1007\%2F978-3-030-44850-9.pdf.

Armstrong, Kathryn. 2021. "Virtual Visibility and the Film Festival Circuit." Afterimage 48 (1): 1018. doi:10.1525/aft.2021.48.1.10.

Bennett, Andy, Jodie Taylor, and Ian Woodward, eds. 2014. The Festivalisation of Culture. Aldershot: Ashgate.

Betzler, Diana, Ellen Loots, Marek Prokůpek, Lénia Marques, and Petja Grafenauer. 2020. "COVID-19 and the Arts and Cultural Sectors: investigating Countries' Contextual Factors Andearly Policy Measures." International Journal of Cultural Policy. doi:10.1080/10286632.2020. 1842383.

Bláhová, Jindřiška. 2015. "National, Socialist, Global. The Changing Roles of the Karlovy Vary Film Festival, 1946-1956." In Cinema in Service of the State: Perspectives on Film Culture in the GDR and Czechoslovakia, 1945-1960, edited by Lars Karl and Pavel Skopal, 245-272. New York and Oxford: Berghahn.

Bohle, Dorothee, and Béla Greskovits. 2012. Capitalist Diversity on Europe's Periphery. Ithaca and London: Cornell University Press. 
Brown, Alan. 2020. "Life After Covid: who will survive?" Arts Professional, March 26. Accessed 19 May 2021. https://www.artsprofessional.co.uk/magazine/article/life-after-covid-who-will-survive

Butter, Susannah. 2019. "Roma director Alfonso Cuarón interview: 'I was making something that came directly from memory." GoLondon, January 31. Accessed 15 May 2019. https://www.standard.co.uk/go/london/film/roma-director-alfonso-cuar-n-interview-oscars-a4053931.html.

de Valck, Marijke, and Antoine Damiens. 2020. "Film festivals and the first wave of COVID-19: Challenges, opportunities, and reflections on festivals' relations to crises." Necsus, December 6. Accessed 20 July 2021. https://necsus-ejms.org/film-festivals-and-the-first-wave-of-covid-19challenges-opportunities-and-reflections-on-festivals-relations-to-crises/

de Valck, Marijke. 2007. Film Festivals: From European Geopolitics to Global Cinephilia. Amsterdam: Amsterdam University Press.

Děcká, Eliška. 2014. "Karnevaly Animátorské Komunity." Iluminace 26 (1): 83-96.

Q4 Drzał-Sierocka, A.et al. 2017. Festiwale Filmowe w Polsce. Raport. Warszawa: Obserwatorium.

DVTV. 2021. "V kinech bude řežba, Netflixu se nebojíme. Točit během covidu byl masakr, říká Bradáč.” DVTV, May 7. Accessed 27 May 2021. https://video.aktualne.cz/dvtv/v-kinech-buderezba-netflixu-se-nebojime-tocit-behem-covidu/r ec7df08aaf3711eb8e470cc47ab5f122/

Elsaesser, Thomas. 2005. European Cinemas: Face to Face with Hollywood. Amsterdam: Amsterdam University Press.

goEast. nd. “The Festival." Accessed 27 May 2021. https://www.filmfestival-goeast.de/en/about/festival.php Grynienko, Katarzyna. 2021. "Polish Film Institute Support During COVID-19 Pandemic." FilmNewEurope.com, April 30. Accessed 27 May 2021. https://www.filmneweurope.com/news/ poland-news/item/121669-polish-film-institute-s-support-during-covid-19-pandemic

Hanzlík, Jan. 2017. "Eventization and Targeting in Czech Theatrical Distribution after 1989." Iluminace 29 (3): 49-64. Accessed 19 July 2021. https://www.iluminace.cz/images/obsah/ Hanzlik_3_2017.pdf.

Havel, Luděk. 2012. "O Nového Člověka, o Dokonalejší Lidstvo, o Nový Festival.' Filmový Festival Pracujících, 1948 až 1959.” In Naplánovaná Kinematografie, edited by Pavel Skopal, 312-357. Praha: Academia.

Hobbins-White, Phil, and Brad Limov. 2020. "SXSW, Amazon, and the Difficulty of Staging an Exclusive Event Online." Necsus 9 (2): 329-338. doi:10.25969/mediarep/15325.

Ji.hlava IDFF. 2020. "Final Report 2020." Accessed 27 May 2020. htps://www.ji-hlava.cz/media/editor/soubory/downloads/2020/24-JIDFF-ZZ_en.pdf

Ji.hlava IDFF. n. d. "About." Accessed 27 May 2020. https://www.ji-hlava.com/o-nas

Jiřiště, Jakub. 2014. "Iluzorní Obrodný Proces Karlovarského Filmového Festivalu. XVI. Mezinárodní Festival Karlovy Vary (1968) v Reflexi Dobového Tisku.” Iluminace 26 (1): 9-38.

Kancereviciute, Aukse. 2020. "Lithuania Tallies COVID-19 Box Office Losses." FilmNewEurope. com, May 25. Accessed 27 May 2021. https://www.filmneweurope.com/news/lithuania-news/ item/120039-lithuania-sees-large-box-office-decline-due-to-covid-19

Kancereviciute, Aukse. 2021. "FNE Market Analysis 2020: LITHUANIA." FilmNewEurope.com, February 2. Accessed 27 May 2021. https://www.filmneweurope.com/news/lithuania-news/ item/121265-fne-market-analysis-2020-lithuania

Kötzing, Andreas. n. d. "Festival History." DOK Leipzig. Accessed 27 May 2021. https://www.dokleipzig.de/en/festival-history

KV IFF and Kancelár Kreativní Evropa - Media. 2020. “Tady industry. Panelová diskuze o tvorbě a distribuci v kinematografii.” Mall.cz, July 10. Accessed 27 May 2020. https://www.mall.tv/ tady-vary/tady-industry-panelova-diskuze-o-tvorbe-a-distribuci-v-kinematografii

LFŠ. 2020. "Videozáznam diskuze 'Filmové festivaly si musí pomáhat.” August 12. Accessed 27 May 2021. https://lfs.cz/filmove-festivaly-si-musi-pomahat/

Martinek, Přemysl. 2014. "Jsou Filmové Festivaly Skutečně Platnou Distribuční Platformou? Instituce Filmového Festivalu Pohledem Distributora 'Festivalových'Filmů.” Iluminace 26 (1): 49-64.

Míšková, Věra. 2021. "Ivo Andrle z české online videopůjčovny Aerovod: Rok 2020 pro nás byl rekordní.” Novinky.cz, January 17. Accessed 27 May 2021. https://www.novinky.cz/kultura/clanek/ ivo-andrle-z-ceske-online-videopujcovny-aerovod-rok-2020-pro-nas-byl-rekordni-40348053 
Nedyalkova, Maya. 2016. "Festivals Gone Digital: A Case-Study of Netcinema.bg and the Online European Film Festival in Bulgaria." In Transformation Processes in Post-Socialist Screen Media, edited by Jana Dudková, and Katarína Mišíková, 138-152. Bratislava: Academy of Performing Arts in Bratislava and Slovak Academy of Sciences.

NIPOS. 2020. "Festivaly 2019." Výběr ze základních statistických údajů o kultuře v české republice. Praha: The National Information and Consulting Centre for Culture. Accessed 27 May 2021. https://www.statistikakultury.cz/wp-content/uploads/2020/12/Statistika_2019_FESTIVALY.pdf

Pabiś-Orzeszyna, Michał. 2015. "Conflict Management: The Camerimage Festival and the Dialectics of Prestige." Iluminace 27 (3): 7-22.

Patton, Michael Quinn. 2015. Qualitative Research \& Evaluation Methods. 4th ed. Thousand Oaks, London, New Delhi, Singapore: Sage.

Peranson, Mark. 2008. "First You Get the Power, Then You Get the Money: Two Models of Film Festivals." Cinéaste 33 (3): 37-43.

Polish Film Festival Gdynia. 2021. “About us.” Accessed 27 May 2021. https://festiwalgdynia.pl/en/ festiwal/o_nas/

Powers, Thom. 2020. "Film Festivals Aren't Just Surviving Online, They're Creating a Better Future", IndieWire, 16 May. Accessed 27 May 2021. https://www.indiewire.com/2020/05/film-festivals-online-future-1202231417/

Rosen, David. 2013. "Film Festivals and the Future of Streaming", Filmmaker Magazine, 9 September. Accessed 27 May 2021. https://filmmakermagazine.com/76064-film-festivals-and-the-future-ofstreaming/\#.YHsyJWhKjFg

Seidman, Irving. 2006. Interviewing as Qualitative Research. A Guide for Researchers in Education and the Social Sciences. 3rd ed. New York and London: Teachers College, Columbia University.

Ševčík, Václav. 2021. "Krizový Management Marienbad Film Festivalu v Krizi Spojené s Pandemií Covidu-19." B.A. Thesis., Prague University of Economics and Business.

Sheth, Jagdish. 2020. "Impact of Covid-19 on Consumer Behavior: Will the Old Habits Return or Die?” Journal of Business Research 117 (September): 280-283. doi:10.1016/j.jbusres.2020.05.059.

Sladký, Pavel. 2020. "Budoucnost filmových festivalů je hybridní, ř́ká ředitel jihlavského MFDF Hovorka." Český rozhlas Vltava, November 10. Accessed 27 May 2021. https://vltava.rozhlas. cz/budoucnost-filmovych-festivalu-je-hybridni-rika-reditel-jihlavskeho-mfdf-hovorka-8358302

Slováková, Andrea. 2020a. "Andrea Slováková uvádí sekci Virtuální Realita - 24th Ji.hlava IDFF. "November 4. YouTube channel "Mezinárodní festival dokumentárních filmů Ji.hlava." Accessed 27 May 2021. https://www.youtube.com/channel/UCoFLul5oiHEf12o5pVrCZfw

Slováková, Andrea. 2020b. "Connecting Festivals, Distributing Films: An Interview with Diana Tabakov, Acquisitions Manager at Doc Alliance Films VOD Platform.” In Documentary Film Festivals Vol. 2 Changes, Challenges, Professional Perspectives, edited by Aida Vallejo and Ezra Winton, 201-210. Cham: Palgrave Macmillan.

Smits, Roderik. 2019. Gatekeeping in the Evolving Business of Independent Film Distribution. Cham: Palgrave Macmillan.

Stejskal, Tomáš. 2021. "S filmem V síti jsme měli kliku, říká šéf Aerofilms Ivo Andrle. Covidu navzdory snímek utržil přes 60 milionů korun.” iHNed.cz, March 5. Accessed 27 May 2021. https://vikend.ihned.cz/c1-66891460-ivo-andrle-aerofilms-rozhovor-koino-aero-filmovadistribuce

Sterritt, David. 2020. "Virtual Cinema." Quarterly Review of Film and Video 37 (6): 505-507. doi:10.1080/10509208.2020.1772655.

Szczepanik, Petr, Pavel Zahrádka, and Jakub Macek. 2020. "Introduction: Theorizing Digital Peripheries." In Digital Peripheries: The Online Circulation of Audiovisual Content from the Small Market Perspective, edited by Petr Szczepanik, Pavel Zahrádka, Jakub Macek, and Paul Stepan, 1-31. Cham: Springer. doi:10.1007/978-3-030-44850-9.Accessed 11 May 2021. https://link. springer.com/content/pdf/10.1007\%2F978-3-030-44850-9.pdf.

Taylor, Steven, Caeleigh A. Landry, Michelle M. Paluszek, Thomas A. Fergus, Dean McKay, and Gordon J. G. Asmundson. 2020. "COVID Stress Syndrome: Concept, Structure, and Correlates." Depression and Anxiety 37 (8): 706-714. doi:10.1002/da.23071. 
Telegraph Olomouc. 2021. “Audiovizuální debata 2.0.” YouTube.com. February 20. https://www.you-

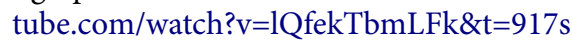

Teslíková, Alice. 2021. "Management Fyzického a Online Filmového Festivalu.” M.A. Thesis., Prague University of Economics and Business.

Točíková Vojteková, Zuzana. 2021. "FNE Market Analysis 2020: SLOVAKIA.” FilmNewEurope.com, February 4. Accessed 27 May 2021. https://www.filmneweurope.com/news/slovakia-news/ item/121268-fne-marketanalysis-2020-slovakia

Vallejo, Aida. 2020. "Introduction to Part I, Vol. 2: Changes and Challenges for Documentary and Film Festivals." In Documentary Film Festivals Vol. 2 Changes, Challenges, Professional Perspectives, edited by Aida Vallejo and Ezra Winton, 13-21. Cham: Palgrave Macmillan.

Vinter, Damijan. 2020. “Slovenian Arthouse Cinemas See Grants Cut By Half." FilmNewEurope.com, November 25. Accessed 27 May 2021. https://www.filmneweurope.com/news/slovenia-news/ item/121041-reduced-funds-for-slovenian-arthouse-cinemas

Vinter, Damijan. 2021. "Slovenian Filmmakers Receive Delayed Payments." FilmNewEurope.com, January 1. Accessed 27 May 2020. https://www.filmneweurope.com/news/slovenia-news/item/ 121181-slovenian-filmmakers-receive-delayed-payments

Virginás, Péter. 2017. "Romanian and Hungarian film cultures at the Transilvania International Film Festival." NECSUS, May 28. Accessed 2 April 2020. https://necsus-ejms.org/romanianand-hungarian-film-cultures-at-the-transilvania-international-film-festival/

Volná, Anna. 2020. “Chování Filmových Festivalů v Době Krize.” M.A. Thesis., Prague University of Economics and Business.

Wallerstein, Immanuel. 1990. "Marx, Marxism-Leninism, and Socialist Experiences in the Modern World-System.” Thesis Eleven 27 (1): 40-53. doi:10.1177/072551369002700104.

Wallerstein, Immanuel. 2004. World-Systems Analysis. An Introduction. Durham: Duke University Press. 